\begin{tabular}{|c|c|c|}
\hline Case Reports in & \multicolumn{2}{|c|}{ Case Rep Gastroenterol 2015;9:361-365 } \\
\hline Gastroenterology & $\begin{array}{l}\text { DOI: 10.1159/000441999 } \\
\text { Publisned onine: November 14, } 2015\end{array}$ & $\begin{array}{l}\text { (c) } 2015 \text { The Author(s) } \\
\text { Published by S. Karger AG, Basel } \\
\text { 1662-0631/15/0093-0361 } \$ 39.50 / 0 \\
\text { www.karger.com/crg }\end{array}$ \\
\hline
\end{tabular}

This article is licensed under the Creative Commons Attribution-NonCommercial 4.0 International License (CC BY-NC) (http://www.karger.com/Services/OpenAccessLicense). Usage and distribution for commercial purposes requires written permission.

\title{
Spontaneous Pneumoperitoneum due to Constipation
}

\author{
Ippei Yamana Tomoaki Noritomi Shinsuke Takeno \\ Tatsuya Hashimoto Keisuke Sato Hideki Shimaoka \\ Ryosuke Yamaguchi Fumiaki Ishii Teppei Yamada Yuichi Yamashita \\ Department of Gastroenterological Surgery, Fukuoka University School of Medicine, \\ Fukuoka, Japan
}

\section{Key Words}

Spontaneous pneumoperitoneum · Constipation · Abdominal pain - Intestinal cystic pneumatosis - Differentiation

\begin{abstract}
We report a rare case of spontaneous pneumoperitoneum. An 82-year-old Japanese male patient was referred to our hospital because of constipation and abdominal pain. Abdominal computed tomography revealed a large amount of feces in the colon and rectum, and free air in the abdomen. Based on these findings, the patient was diagnosed with gastrointestinal perforation. Emergency exploratory laparotomy was performed. Neither perforation nor ischemic changes were recognized in the digestive tract. The patient's defecation was managed postoperatively until discharge on the 13th postoperative day. The authors assumed that free air, which was released after a mucosal injury due to the internal pressure caused by the presence of a large amount of feces in the colon and rectum, had penetrated the bowel wall through the bowel mucosa. We herein report the present case while also reviewing the pertinent literature.

\section{Introduction}

Pneumoperitoneum is often caused by the perforation of the digestive tract. Gastric or duodenal perforations due to peptic ulcer are the most common causes of pneumoperitoenum. The presence of pneumoperitoneum usually indicates the need for emergency laparotomy. However, surgery is not required in cases of pneumoperitoneum where there is no evidence of visceral perforation caused by a physiological process. This status, termed spon-

KARGER 125/s $\quad \begin{aligned} & \text { Ippei Yamana, MD } \\ & \text { Department of Gastroenterological Surgery } \\ & \text { Fukuoka University School of Medicine } \\ & \text { Nanakuma 7-45-1, Jonan-ku, Fukuoka 814-0180 (Japan) } \\ & \text { E-Mail 3949noex@jcom.home.ne.jp }\end{aligned}$


Yamana et al.: Spontaneous Pneumoperitoneum due to Constipation

taneous pneumoperitoneum (SP), is reported to occur in 14-23\% of all patients with pneumoperitoneum $[1,2]$. Generally, SP is not complicated by peritonitis, is benign and can be treated conservatively. In addition, pneumoperitoneum without peritonitis is a rare phenomenon which creates a management dilemma for the treating surgeon. The diagnosis of SP is difficult; thus, SP patients may undergo unnecessary surgery. The dilemma in the treatment of SP lies in deciding between a laparotomy and a conservative line of management. So far, various reports with causes of SP have been discussed, and they have not been clear yet. In our case, although computed tomography (CT) showed free air in the abdomen, the perforation of the digestive tract was not recognized during the exploratory laparotomy. The aim of this report is to present a case of SP of undetermined origin, and to discuss the possible etiology.

\section{Case Report}

An 82-year-old Japanese male patient was referred to our hospital due to constipation and abdominal pain for 3 days. A physical examination revealed lower abdominal tenderness and distention. Muscular defense was not recognized. The patient's medical history included distal gastrectomy for gastric ulcer (20 years previously) and community-acquired pneumonia ( 3 weeks previously). The patient did not take any medications and did not smoke or consume alcohol. The laboratory data showed an abnormal white blood cell (WBC)

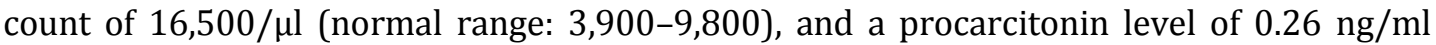
(normal range: $<0.05$ ). All of the other laboratory data were within the normal ranges. Abdominal CT revealed a large amount of feces in the colon and rectum, and free air in the abdomen (fig. 1a). Intestinal cystic pneumatosis was recognized in the colon (fig. 1b). A diagnosis of gastrointestinal perforation was suspected based on the imaging findings. Three hours after coming to the hospital, emergency exploratory laparotomy was subsequently performed but revealed no evidence of perforation or ischemic changes in the digestive tract (fig. 2). Finally, because the cause of the pneumoperitoneum could not be identified, the operation was completed by placing a closed drain in the abdomen. The postoperative course was uneventful. The patient's defecation was managed until discharge on the 13th postoperative day.

\section{Discussion}

Pneumoperitoneum without peritonitis is a rare phenomenon which creates a management dilemma for the treating surgeon. As a result of this diagnostic dilemma, the patient may be subjected to unnecessary laparotomy.

Gantt et al. [3] suggested that the origin of SP indicated intra-thoracic, intra-abdominal, gynecological, and iatrogenic causes. The intra-thoracic causes include barotrauma pneumothorax [4], bronchoperitoneal fistula [5], pneumomediastinum [6], and mechanical ventilation [7]. The intra-abdominal causes include abdominal emphysematous cholecystitis [8], spontaneous bacterial peritonitis [9], intestinal cystic pneumatosis [10-15], and liver abscess [16]. The gynecological causes include rupture of pyometra [17]. The iatrogenic causes include endoscopic procedures such as colonoscopy [18]. Most of the reported cases of SP occurred as iatrogenic complications.

Intestinal cystic pneumatosis was first described by Du Vernoi [10] in 1783 and documented in greater detail by Bang [11] in 1876. Intestinal cystic pneumatosis is mostly 
Yamana et al.: Spontaneous Pneumoperitoneum due to Constipation

asymptomatic. The etiology and pathogenesis of intestinal cystic pneumatosis have been controversial. Several theories have been suggested based on different observations, including the penetration of luminal gas through the bowel mucosa into the bowel wall after mucosal injury [12], pulmonary gas released from the ruptured alveoli dissecting the vascular channels in the mediastinum and tracking through the retroperitoneum into the mesenteric root [13], gas production of some bacteria that invade through the mucosal breaches into the intramural compartments or grow within microscopic cysts [14], and gas production related to defects in food digestion causing excessive fermentation [15].

In our case, abdominal CT revealed the presence of a large amount of feces in the colon and rectum, and free air in the abdomen. In addition, intestinal cystic pneumatosis was recognized in the colon. The authors assumed that free air, which was released after a mucosal injury due to internal pressure caused by the presence of a large amount of feces in the colon and rectum, had penetrated the bowel wall through the bowel mucosa. There are no reports of SP occurring secondary to intestinal cystic pneumatosis caused by a large amount of feces.

There are few reports of patients who were diagnosed with SP in the preoperative stage. Most SP patients undergo exploratory laparotomy. Chandler et al. [19] reported that $28 \%$ patients with misleading pneumoperitoneum findings were subjected to operations that, in retrospect, might not have been necessary. Mularski et al. [2] identified 196 case reports of SP patients, among which 45 underwent exploratory surgery without any evidence of perforated viscus. We therefore suggest that it is very difficult for surgeons to diagnose SP and indicate the correct course of treatment.

In conclusion, a thorough medical history, appropriate laboratory tests, radiological techniques and physical examinations might be valuable tools for diagnosing SP and avoiding unnecessary laparotomy. We suggest that in uncertain cases, SP should be differentiated from free air resulting from gastrointestinal perforation and patients should be referred for emergency exploratory laparotomy.

\section{Statement of Ethics}

The published research is compliant with the guidelines for human studies and animal welfare regulations.

\section{Disclosure Statement}

All authors report no conflict of interest related to this paper.

\section{References}

1 Roh JJ, Thompson JS, Harned RK, Hodgson PE: Value of pneumoperitoneum in the diagnosis of visceral perforation. Am J Surg 1983;146:830-833.

2 Mularski RA, Sippel JM, Osborne ML: Pneumoperitoneum: a review of nonsurgical causes. Crit Care Med 2000;28:2638-2644.

-3 Gantt CB Jr, Daniel WW, Hallenbeck GA: Nonsurgical pneumoperitoneum. Am J Surg 1977; 134:411-414.

$\checkmark 4$ Canivet JL, Yans T, Piret S, Frere P, Beguin Y: Barotrauma-induced tension pneumoperitoneum. Acta Anaesthesiol Belg 2003;54:233-236.

5 Hsu PS, Lee SC, Tzao C, Chen CJ, Cheng YL: Bronchoperitoneal fistula from a lung abscess. Respirology 2008:13:1091-1092. 
Yamana et al.: Spontaneous Pneumoperitoneum due to Constipation

6 Lin MC, Lee CL, Chen CY, Rau RH: Pneumoperitoneum complicated pneumomediastinum causing cardiovascular deterioration in a low-body-weight premature infant during laparoscopic Nissen fundoplication. Acta Anaesthesiol Taiwan 2013;51:177-179.

7 Marian K, Monika K, Bartosz K: Spontaneous pneumoperitoneum in a patient after ventilation therapy. Pol Przegl Chir 2015;86:601-603.

-8 Modini C, Clementi I, Simonelli L, Antoniozzi A, Assenza M, Ciccarone F, Bartolucci P, Ricci G, Petroni R: Acute emphysematous cholecystitis as a cause of pneumoperitoneum. Chir Ital 2008;60:315-318.

-9 Lai FC, Wu CC, Hwu DH, Liu TJ, P'eng FK: Pneumoperitoneum caused by spontaneous bacterial peritonitis: a case report. Zhonghua Yi Xue Za Zhi (Taipei) 1994;54:373-375.

10 Du Vernoi JG: Anatomische Beobachtungen der unter der äussern und innern Haut der Gedärme eingeschlossenen Luft. Phys Med Abhandl Akad Wiss Petersb 1783;2:182-188.

11 Bang BLF: Luftholdige kyster i vaggen af ileum og i nydannet bindevav pasammes serosa [Cysts in the walls of ileum and in neoplasm of connective and serous tissues]. Nordiskt Mediciniskt Arkiv 1876;8:1-15.

12 Galanduik S, Fazio VW, Petras RE: Pneumatosis cystoides intestinalis in Crohn's disease. Dis Colon Rectum 1985;28:951-956.

13 Doub HP, Shea JJ: Pneumatosis cystoides intestinalis. J Am Med Assoc 1960;172:1238-1242.

14 Koss LG: Abdominal gas cysts (pneumatosis cystoides intestinorum hominis): an analysis with a report of a case and critical review of the literature. AMA Arch Pathol 1952;53:523-549.

15 Coello-Ramirez P, Gutierres-Topete G, Lifshitz F: Pneumatosis intestinalis. Am J Dis Child 1970;120:3-9.

16 Kim JH, Jung ES, Jeong SH, Kim JS, Ku YS, Hahm KB, Kim JH, Kim YS: A case of emphysematous hepatitis with spontaneous pneumoperitoneum in a patient with hilar cholangiocarcinoma. Korean J Hepatol 2012;18:9497.

17 Shapey IM, Nasser T, Dickens P, Haldar M, Solkar MH: Spontaneously perforated pyometra: an unusual cause of acute abdomen and pneumoperitoneum. Ann R Coll Surg Engl 2012;94:246-248.

18 Baccaro LM, Markelov A, Wilhelm J, Bloch R: Pneumoperitoneum after virtual colonoscopy: causes, risk factors, and management. Am Surg 2014;80:549-554.

19 Chandler JG, Berk RN, Golden GT: Misleading pneumoperitoneum. Surg Gynecol Obstet 1977;144:163-174.
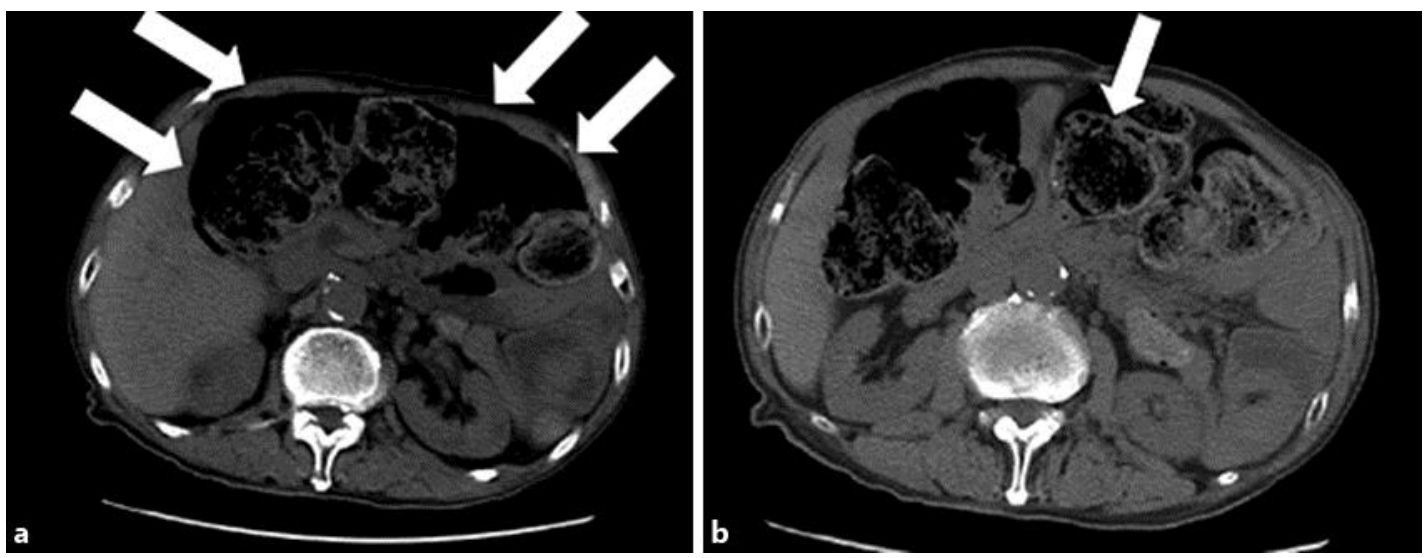

Fig. 1. a Abdominal CT revealed a large amount of feces in the colon and rectum and free air in the abdomen (arrows). b Intestinal cystic pneumatosis was recognized in the colon (arrow). 


\begin{tabular}{ll|l} 
Case Reports in & & \multicolumn{2}{c}{ Case Rep Gastroenterol 2015:9:361-365 } \\
\cline { 2 - 3 } Gastroenterology & DOI: 10.1159/000441999 & $\begin{array}{l}\text { ○ 2015 The Author(s). Published by S. Karger AG, Basel } \\
\text { www.karger.com/crg }\end{array}$ \\
\cline { 2 - 3 } & Yamana et al.: Spontaneous Pneumoperitoneum due to Constipation
\end{tabular}

Yamana et al.: Spontaneous Pneumoperitoneum due to Constipation

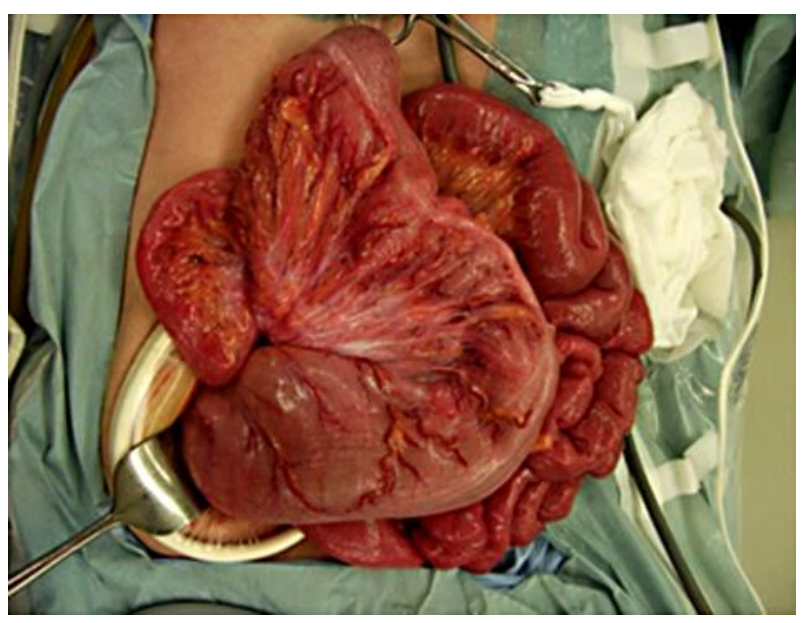

Fig. 2. At laparotomy, no evidence of perforation or ischemic change was recognized in the digestive tract. 